\title{
Raloxifene reduced vertebral fractures and breast cancer regardless of prior hormone therapy use in women
}

Johnell O, Cauley JA, Kulkarni PM, et al. Raloxifene reduces risk of vertebral fractures and breast cancer in postmenopausal women regardless of prior hormone therapy. J Fam Pract 2004;53:789-96.

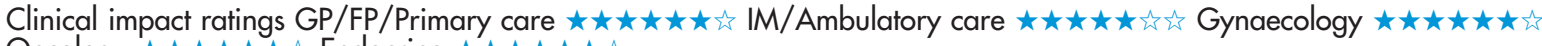

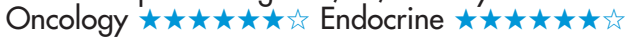

In postmenopausal women with osteoporosis, does previous hormone therapy (HT) influence the effect of raloxifene on the risk of vertebral fractures and breast cancer?

\section{METHODS}

$\square$

Design: randomised placebo controlled trial (the Multiple Outcomes of Raloxifene Evaluation [MORE] trial).

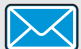

Allocation: $\{$ concealed*\}†.

2

Blinding: blinded \{patients, healthcare providers, and outcome assessors\}t.*

$\sum<$

Follow up period: 4 years.

Setting: $\{180$ clinical centres in 25 countries $\} \dagger$

Patients: 7705 postmenopausal women $\leqslant 80$ years of age (mean age $67 \mathrm{y}$ ) with osteoporosis. 7682 women $(99.7 \%$ ) reported HT status; 2235 women (29.1\%) had used HT previously. Exclusion criteria included other bone diseases and history of breast or endometrial cancer

D Intervention: among women with prior $\mathrm{HT}$ use, raloxifene, 60 $\mathrm{mg} /$ day or $120 \mathrm{mg} /$ day $(\mathrm{n}=1497)$, or placebo $(\mathrm{n}=738)$.

Among women without prior HT use, raloxifene, $60 \mathrm{mg} /$ day or $120 \mathrm{mg} /$ day $(n=3614)$ or placebo $(n=1833)$. All women received daily supplementation with calcium, $500 \mathrm{mg}$, and vitamin D, 400-600 IU

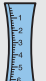

Outcomes: new vertebral fractures, breast cancer, and cardiovascular events.

Patient follow up: $88 \%$.

*See glossary.

†Information from JAMA 1999;282:637-45

\section{MAIN RESULTS}

Regardless of prior HT use, raloxifene, $60 \mathrm{mg} / \mathrm{day}$, reduced new vertebral fractures compared with placebo (table); raloxifene, $60 \mathrm{mg}$ /

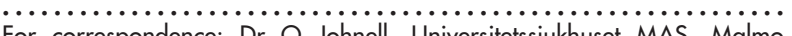
Sweden. olof.johnell@orto.mas.lu.se

Source of funding: none stated. day and $120 \mathrm{mg} /$ day pooled doses, reduced breast cancer compared with placebo (table). Raloxifene and placebo did not differ for incidence of cardiovascular events.

\section{CONCLUSION}

Raloxifene reduced vertebral fractures and breast cancer regardless of prior hormone therapy use in postmenopausal women with osteoporosis.

\section{Commentary}

The large, randomised MORE trial by Johnell et al previously reported reduction in vertebral fracture risk and breast cancer risk by raloxifene in a group of women selected on the basis of having low bone mineral density or pre-existing vertebral fracture, or both. This new study determined whether self reported prior menopausal HT influenced raloxifene's ability to prevent vertebral fractures or to reduce breast cancer risk.

This analysis was not preplanned; thus, it is not surprising that women who used HT before participating in MORE had different characteristics from those who had not. Women who had prior HT use had a lower baseline bone density than women who had no prior HT use. The authors posit that baseline differences, such as residual protective effects of oestrogen, may explain the differential reduction in vertebral fracture risk by raloxifene between women who had prior HT use and those who had not.

The other major finding of this study was that breast cancer risk was reduced to a comparable extent in women who had and had not taken HT. No formal breast cancer risk assessment was done at the initiation of the MORE trial. Thus, subgroup analysis of high risk women was not possible.

Many questions remain. Even if raloxifene receives US Food and Drug Administration approval for breast cancer risk reduction in the future, head to head trials comparing efficacy and adverse effects of raloxifene, tamoxifen, and aromatase inhibitors are not yet available. Moreover, many women who discontinue oestrogen therapy will choose bisphosphonates instead of raloxifene because raloxifene has not been shown to reduce hip fracture risk. Until completion of pending studies (such as the Study of Tamoxifen and Raloxifene [STAR] trial comparing tamoxifen and raloxifene for preventing breast cancer), tamoxifen will remain the choice for breast cancer risk reduction and bisphosphonates will remain the treatment of choice to prevent hip fractures in women with osteoporosis.

Carolyn Crandall, MD, MS, FACP Los Angeles, California, USA

1 Wickerham DL. Recent Results Cancer Res 2003;163:87-95.

Raloxifene (Ral) v placebo for postmenopausal osteoporosis with or without prior hormone therapy (HT) use at 4 years*

\begin{tabular}{|c|c|c|c|c|c|}
\hline Outcomes & Population & Comparisons & Event rates & $\operatorname{RRR}(95 \% \mathrm{Cl})$ & NNT (Cl) \\
\hline $\begin{array}{l}\text { New vertebral } \\
\text { fractures } \\
\text { Breast cancer }\end{array}$ & $\begin{array}{l}\text { Women with prior HT use } \\
\text { Women without prior HT use } \\
\text { Women with prior HT use } \\
\text { Women without prior use }\end{array}$ & $\begin{array}{l}\text { Ral, } 60 \mathrm{mg} / \mathrm{d} \text {, } \\
v \text { placebo } \\
\text { Ral, } 60 \text { or } 120 \mathrm{mg} / \mathrm{d} \text {, } \\
v \text { placebo }\end{array}$ & $\begin{array}{l}5.7 \% \vee 12.4 \% \\
9 \% \vee 12.7 \% \\
0.73 \% \vee 2.3 \% \\
0.64 \% \vee 1.47 \%\end{array}$ & $\begin{array}{l}54 \%(33 \text { to } 68) \\
29 \%(13 \text { to } 42) \\
68 \%(34 \text { to } 85) \\
56 \%(25 \text { to } 75)\end{array}$ & $\begin{array}{l}15(11 \text { to } 28) \\
28(18 \text { to } 64) \\
64(34 \text { to } 182) \\
121(66 \text { to } 352)\end{array}$ \\
\hline
\end{tabular}

*Abbreviations defined in glossary; RRR, NNT, and Cl calculated from data in article. 